\title{
SURVEY AND ANALYSIS THE CRITICAL SUCCESS FACTORS IN THE REVERSE FLOW INVENTORY MANAGEMENT PROCESS FOR RETURNABLE PACKAGING
}

Wesley Douglas Oliveira Silva wesley.douglas142836@gmail.com Federal University of Pernambuco, Caruaru, PE, Brazil

Marcele Elisa Fontana marcelelisa@gmail.com

Federal University of Pernambuco, Caruaru, PE, Brazil

\section{ABSTRACT}

Goal: This study aimed to propose a procedure to survey of the Critical success Factors (CSF) in the reverse flow inventory management.

Design / Methodology / Approach: A problem structuring method (PSM) combined with an approach for analysis of strategic map were used to facilitate and share information in a participatory process, considering all the stakeholder's perspectives in order to identify and analyse the CSF. A case study of returnable packaging in the metallurgy and steel industry was conducted to validate the proposal.

Results: The proposal was able to minimize conflicts and it facilitated the discussions on the CFSs surveyed. In addition, the decision makers have confirmed that their viewpoints were well represented in the strategic map, and they will use the CFS to evaluate the operations performance.

Limitations of the investigation: Although the surveyed CSFs are specific to the presented case study, the procedure may be replicated in other organizations to identify their own CSF.

Practical implications: The adequate survey of CSFs is fundamental because they have potential to explain the success or failure of a company, since CSFs impact directly on profits, processes performance and competitive environment.

Originality / Value: The main contribution was to propose a methodology to survey critical success factors in the reverse flow environment adequate to messy, complex and unstructured situations, as well as this methodology was able to make a cyclic analysis and comprehension of the multiple perspectives, important in group decision maker environments.

Keywords: Reverse Logistics; Critical Success Factors; Inventory Management; Soft Operational Research; Strategic Options Development and Analysis (SODA). 


\section{INTRODUCTION}

The increasing concern about environmental and energy conservation leads enterprises to rethink about their market position, reformulate the strategy, and reengineer the business processes" (Lee and Lam, 2012, p. 1).

In this sense, reverse logistics (RL) is a concept that have been being largely discussed due to its potential to respond to environmental, financials and social impacts (Yui et al., 2017; Muniz Junior and Cunha, 2017).

Hence, RL can be defined as

"The process of planning, implementing and regulating the efficient and cost-effective flow of raw materials, in-process inventory, finished goods and related information from the point of consumption to the point of origin". (Rogers and Tibben-Lemke, 1999, p. 2)

According to Govindan and Soleimani (2017) from the evolution of the supply chains these began to integrate the direct and reverse flows simultaneously resulting in the Closed Loop Supply Chain (CLSC).

In this sense, Guide and Van Wassenhove (2009) defined the CLSC "as the design, control and operation of a system to maximize value creation over the entire life cycle of a product with dynamic recovery of value from different types and volumes of returns over time".

In this context, managers showed two main goals: (a) decrease the inventory level, reducing and balancing the inventory maintenance costs and order costs; and (b) improve the material management through the supply chain (SC). Since inventories can provide security against the risk of lack of goods in SC, efficient material management becomes even more relevant (Bogataj and Grubbstr, 2013).

However, inventory management studies tend to focus on the direct flow rather than on reverse flow. One reason for this is the barriers to RL deployment, such as: economic, technology, infrastructure, knowledge, policy, governance and supply chain process related issues (Bouzon et al., 2016).On the other hand, Chileshe et al. (2015) emphasized significant benefits that may encourage companies to implement $R L$, such as: legislation requirements, profit-oriented and improved their corporate image. Thus, both, benefits and barriers, must be taken into consideration by companies when deciding to implement reverse logistics, and it has become a strategic issue for the companies.

Furthermore, some facts are common when inventory management in reverse flow is considered. Da et al. (2004) highlighted the following points: i) small inventories and/ or badly conditioned ones; ii) recovery flow with high uncertainty rate; iii) some warehouse operations, such as cross docking, are not possible due to a lack of real time tracking; iv) there is a poor integration of the process that makes it impossible to immediately allocate the returned goods; and v) high costs to establish the appropriate remanufacturing process for the returned materials due the poor integration.

In recent times, an increase in the use of returnable rather than disposable packaging has been being observed (Twede and Clarke, 2005). In the context of RL, returnable packaging means a change in the behaviour from the companies in relation to the environment for both objectives the environmental sustainability and businesses competitiveness (Yusuf et al., 2017). Thus, manage inventories of returnable packaging represents a relevant problem in reverse flow decisions.

However, decisions on inventory management in the reverse flow can be complex because this type of decision making may involve a group of decision makers (DM), who can show different viewpoints and conflicting interests; each acting on their own opinions and using different value systems, which need to be considered in order evaluate appropriate actions to solve the problem (Eden and Ackermann, 2006; Morais and De Almeida, 2009; Rouwette et al., 2011).

Regarding the literature review, aspects and characteristics of inventory management in reverse flow, especially on returnable packaging, are not yet sufficiently discussed (Dem and Prasher, 2013; Raj et al., 2014; Matar et al., 2014). On the other words, this topic represents a gap in the literature.

Therefore, a way to minimize inventory management problems related to returnable packaging is through a good management of their Critical Success factors (CSF) (Turner, 2009). Overall, CSF well-designed can reduce the costs and improve the communication among the parts and the coordination of activities and functions that allows an effective integration between forward and reverse flows (Brun 2011; Cherubini et al. 2015; Himme, 2012; Usman and Callum, 2013). The soft operational research methodologies were developed to aid companies in complex situations. In this sense, Problem Structuring Methods (PSM) can be highlighted (Mingers and Rosenhead, 2004).

"The PSM explore mental models of decision makers and identify cognitive aspects that lead to reflection of future consequences of choices and decisions". (Cunha et al., 2016, p. 2) 
In addition, in many areas, the PSMs have been used, especially in group decision making, where the actors of the process may present conflicting interests and they are faced with a complex problem situation and need support in understanding the problem, its consequences, actions and objectives (Cunha and Morais, 2017; Keisler et al., 2014; Wang et al., 2015). The use of PSM in inventory management decisions in reverse flow, specifically related to returnable packaging, was not observed yet in other studies, which is another gap in the literature.

In this sense, the aim of this paper was to survey and analysis the CSFs in the reverse flow inventory management process for returnable packaging. For that, this study proposed the use of a PSM, Strategic Options Development and Analysis (SODA), in order to capture and analyse the decision maker perspectives, and an additional approach for analysis of strategic map to survey the CSF. The SODA works individual cognitive map that are aggregated into a global map or strategic map. After that, an approach for analysis this global map was used to make additional findings and improve the decision-making environment. The SODA methodology was used because it is a useful tool to support group decision making in strategic analysis processes. This methodology is very efficient regarding the need for cognitive changes in favour of consensus and greater commitment of the decision makers with the final decision (Videira et al., 2016). A case study on returnable packaging in a metallurgy and steel industry was conducted.

To sum up, this study is also relevant, since Veiga (2013) stated that in Brazil, for example, waste generation has grown at a level three times faster than the population, and most of their municipalities are unable to find suitable disposal sites such as landfills. In this sense, Farel et al. (2013) argued that the capacity of landfills has become more expensive, which limits their use. Therefore, managing goods in the end of their useful lives and allocating them properly through the CLSC is indispensable for environmental preservation and society development.

Besides this introduction, this work was structured as follows: in Section 2 a brief review of returnable packaging and CSF was made; in Section 3 the methodology proposed was presented; in Section 4 the case study was reported and some discussions were performed; finally, some concluding remarks was made.

\section{A BRIEF REVIEW}

According Levi et al. (2011), packaging is a fundamental component of the manufacturing system since it can protect goods while they are being transported from providers to customers. Silva et al. (2013) affirmed that packaging may be classified, basically, into two categories: (1) multiway, i.e., packaging that can be returned and reused by organizations; and (2) one-way, i.e., disposable packaging that have reached their end-of-life (EOL).

Thereby, companies must consider the effect of the packaging on their process performance, as well as consider the compatibility between the packaging and their processes, products and the environment (Silva et al., 2013; Levi et al., 2011; Zhang et al., 2015).

In the literature, there are several studies that have been conducted about packaging. In this sense, three research fields stand out. The first is concerned about the performance evaluation of different types of packaging, in order to define which one is the best option for each situation presented (Carrano et al., 2015; Dang and Chu, 2016; Doorsselaer and Lox, 1999; Grimes-Casey et al., 2007; Levi et al., 2011; Menesatti et al., 2012; Palsson et al., 2013; Silva et al., 2013; Singh et al., 1999; Zhang et al., 2015).

The second field describes the benefits of utilizing some types of packaging rather than others in the situations explored (Beitzen-Heineke et al., 2017; Dubiel, 1996; Mazeika Bilbao et al., 2011; Mollenkopf et al., 2005). Finally, the third field proposes models to manage the systems which includes the returnable packaging in order to achieve the objectives and functions they were set up (Atamer et al., 2013; Bottani et al., 2015; Chew and Huang, 2002; Kim et al., 2014; Thoroe et al., 2009; Tsiliyannis, 2005). However, these authors did not study the inventory management in reverse flow, and they did not explore approaches of stakeholder's coordination among the RL processes. In addition, most of these researches were conducted in developed countries, which present an effective infrastructure different from underdeveloped countries.

Furthermore, processes which utilize returned packaging need to be well managed because they are part of the company's strategies. For this reason, companies must plan the execution of their processes in order to guarantee that their strategies are being reflected on them (Chenhall, 2003). Thus, this planning may be done through the critical success factors (CSF).

Hence, according to Sampedro et al. (2010), a CSF is defined as the factor which can explain the success or failure of a company and have a significant impact on profits and losses, being representative of the changes in the competitive environment. In this sense, recent studies on the CSF have explored: project management (Banihashemi et al., 2017; Costantino et al., 2015; Ika et al., 2012; Rodríguez-Segura et al., 2016); business processes 
management (Alhuraish et al., 2017; Ali and Kidd, 2013; Bai and Sarkis, 2013; Cherubini et al., 2015); and Information Technology (Alreemy et al., 2016; Fayaz et al., 2017; Bhuasiri et al., 2012; Ozorhon and Karahan, 2017). However, in the reverse logistics context the CSF werenot widely explored.

Mangla et al. (2015), for example, identified the CSF for the implementation and prioritization of the RL process, using Analytical Hierarchy Process (AHP) and Decision-Making Trial and Evaluation Laboratory (DEMATEL) methods. While, Agrawal et al. (2016) proposed Fuzzy-Technique for Order Preference by Similarity to Ideal Solution (TOPSIS) method to prioritize the CSF in the RL. None of these work considered returned packaging. Moreover, they presupposed a structured problem situation. However, as previously mentioned, problems in $\mathrm{RL}$, in general, are complex and unstructured, where alternatives and criteria are not clearly defined. Thus, this paper aimed on filling this gap on the literature. In this sense, the methods of soft operational research may be used to develop an approach to deal with these opportunities.

\section{Soft Operational Research (SOR)}

Fundamentally, according to Yolles (2010, p. 1), Soft Operational Research (SOR)

"Is concerned with complex, messy and unclear situations in which there are few universals, and where perspectives in any social environment is relativistic and pluralistic though the multiplicity of people who compose the social".

In this context, participative methods have been developed in order to help the interested parts to achieve engagement in decisions making to address complex issues, such as: organizational, social, environmental or technological (Midgley et al., 2013). Among the participatory methods are the Problem Structuring Methods (PSMs).

The PSMs are characterized by the use of some tools to structure a problem situation facilitating the negotiation and agreement between the stakeholder (Eden and Ackermann, 2006; Konsti-Laakso and Rantala, 2018). In this sense, the main methodologies are: Soft Systems Methodology (SSM), Strategic Choice Approach (SCA) and Strategic Options Development and Analysis (SODA). Particularly, this work used SODA, since this methodology considers the uncertainties inherent of RL, and the presence of a group of decision-makers (DMs) who have different perspectives on the problem. These DMs and their perspectives make the problem complex.
Strategic Options Development and Analysis (SODA)

SODA was developed by Eden and Ackermann (2001) and they described that SODA aims to capture the individual's understanding of a problem situation without removing the subjectivity inherent in the context. For this, cognitive maps (CM) are used. They are visualized and discussed in facilitated meetings, in order to find de problem characterization and allowing the learning about it (Eden, 2004; Rouwette et al., 2011). According to Eden and Ackermann (2001), the general stages for application of SODA are the following:

$\checkmark$ Stage 1 - Planning Meetings: The facilitator gives an initial overview of the problem. Thus, the decision makers (DMs) and the desired outputs are defined;

$\checkmark$ Stage 2 - Construction of Individual Cognitive Maps: the DMs are interviewed, individually, to identify their opinions on the subject in question. At this stage individual CMs are constructed. DMs define the problem label, and, after that, they have to issue words which address the problem. These words are called Primary Elements of Evaluation (PEE). The PEE must be complemented by phrases that reflect the importance of this PEE to the problem. These phrases are called present poles. After that, the DMs are asked about the consequences of not executing or not having the present poles. So that, the DMs issue phrases based on these consequences. These new phrases are the opposite poles. Together, the present and opposite pole make the concepts that represent the constructs of the (CMs. The constructs are graphic representations of the concepts in the CMs. Finally, the DMs have to identify the relations among constructs placing arrows on them. The arrows represent the causality relation in the CMs, and DMs place arrows until they fell satisfied about the problem representation with the maps they have constructed individually;

$\checkmark$ Stage 3 - Construction of the Strategic Map: the facilitator aggregates the individual maps into a global map. He/she will use value judgment to link such maps in order to represent the ideas expressed by each DM in their individual map. Moreover, the facilitator needs to unite concepts that are related to each other and establish the relationships between these concepts (Rosenhead and Mingers, 2001). DMs are asked about their satisfaction on the global map. If they are satisfied, the map is finalized; otherwise go to stage 4;

$\checkmark$ Stage 4 -Construction of the Strategic Map with Group Interaction: the resulting map from stage 3 is worked together with DMs at meetings, called workshops, expanding it according to what is presented and discussed until DMs consider the resulting map acceptable and feel that the situation is well represented. In some situations, the facilitator may choose to directly develop the global map through workshops. 
Guarnieri et al. (2016) proposed the SODA in RL in order to structure the electronic waste problem resulting in a portfolio of actions to be developed by stakeholders through shared responsibility under the national solid waste policy. However, although it is related to RL, they have not studied CSFs. In addition, they did not perform additional analyses on $\mathrm{CMs}$ that allow extracting more information, improving the consensus process.

\section{Analysis of the Strategic Map}

In sequence, the strategic map may be analysed. Fontana and Holanda (2019) used this CM analysis to identify alternatives for strategic operations in post-sale reverse logistics, but they considered a situation with only one DM. Thus, for multiple DMs, this approach is based on the categorization of the global map's constructs. The constructs may be structurally categorized according to following types such as (Arlinghaus et al., 2002; Fontana and Holanda, 2019; Georgiou, 2010; Georgiou, 2012):

$\checkmark \quad$ Tails: there are no constructs leading into them. They are also defined as primary causes.

$\checkmark \quad$ Heads: there are no constructs leading out of them. "They reflect objectives, outcomes, results, or consequences stemming from the dependency paths of arrows that lead into them" (Georgiou, 2012, p. 6).

$\checkmark \quad$ Strategic Options: those constructs immediately lead into a head. They reflect the options available through which a particular result (head) may materialize.

$\checkmark \quad$ Implosions: these constructs show a high number of constructs that lead into them. It indicates an important effect and is affected by several other constructs and, consequently, multiple regions of the map. In order to identify the implosions, a quantitative analysis is necessary, called by Implosion Degree (ID). Let $i$ be a construct, where $i=\{1,2, \ldots ., n\}$, the Implosion Degree of a construct $i\left(\mathrm{Id}_{\mathrm{i}}\right)$ is calculated by the sum of the arrows entering (AE) in the construct $i$, as in Equation 1:

$I D i=\Sigma A E \forall i$

$\checkmark$ Explosions: these constructs show a high number of constructs that lead out of them. It indicates an important cause and affects several other constructs and, consequently, various regions of the map. The Explosion Degree (ED) is calculated to identify the explosions. Thus, the Explosion Degree of a construct $i\left(\mathrm{Ed}_{\mathrm{i}}\right)$ is given by the sum of the arrows leaving (AL) the construct $i$, as in Equation 2 .

$E \mathrm{D} i=\Sigma \mathrm{AL} \forall i$ $\checkmark$ Dominants: these are constructs that show a "high total number of constructs leading into them and leading out of them. A construct with a high Domain Degree (DD) indicates cognitive centrality of an issue in DM perceptions, and/or central relevance of an issue to the situation in question" (Georgiou, 2012). A construct dominant is affected by several other constructs and, consequently, various regions of the map. Thus, the Domain Degree of a construct $i\left(\mathrm{DD}_{\mathrm{i}}\right)$ is calculated as in Equation 3:

$\mathrm{DD} i=I \mathrm{D} i+E \mathrm{D} i \forall i$

Therefore, constructs categorized as "dominants offer a good indication of the major issues that must be tackled in order to reach the heads" (Georgiou, 2012). Therefore, those constructs identified as dominants will be considered as CSF.

\section{METHODOLOGY}

The present study was divided into three main steps and subdivided into stages as can be seen in Figure 1.

$\checkmark$ Step 1 - Maps elaboration: in this step the facilitator will follow the stages of SODA's application process, proposed by Eden and Ackermann (2001), as showed in the previous Section. Two planning meetings were made together with the decision makers (DMs) in order to obtain more information about this study and apply the SODA's dynamic. All DMs were interviewed individually, in the same day, in order to get their viewpoints and perspectives about the problem, so that they could not influence each other's map. Once the individual maps have been elaborated, the facilitator aggregated them into a global map, without DMs aid. It resulted in a strategic map. Finally, the strategic map was debated together with the DMs to achieve a consensus about the final map;

$\checkmark$ Step 2 - Map analysis: this phase aimed to classify the constructs from the global map (step 1), and to identify the Critical Success Factors for de problem. If the DMs consider that the CSF surveyed are not properly representing the problem situation, the process restarts on Step 1 until the DMs are satisfied about the CSF; and

$\checkmark$ Step 3 - Critical Success Factors analysis: finally, the CSF were analysed in order to describe and define their importance for the process in context.

\section{RESULTS AND DISCUSSIONS}

"Z Company", a fictitious name, is a Brazilian company that works in the engineering and production of light metals, going from the mining to production adding high value. In 


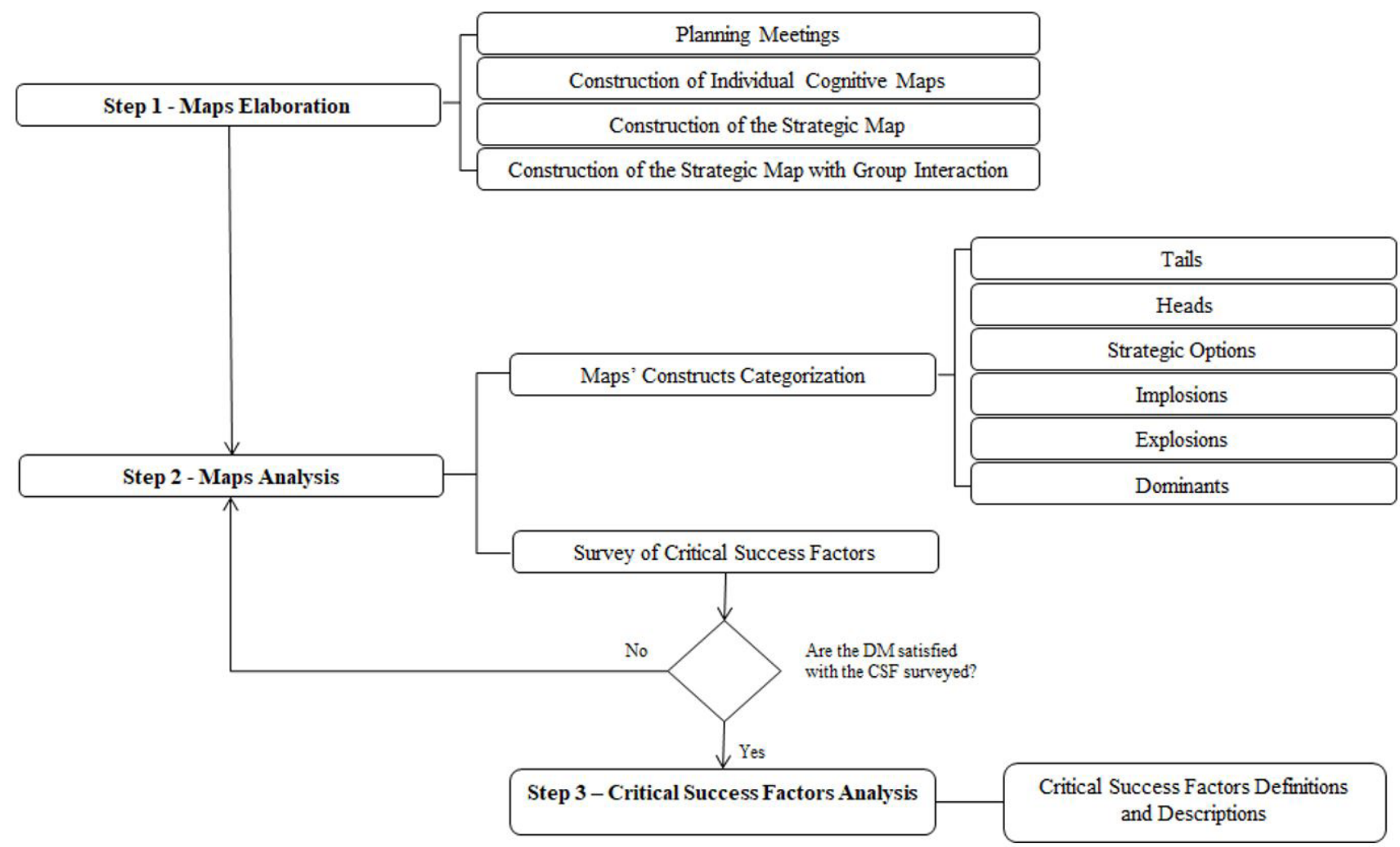

Figure 1.Proposed Methodology

Source: The authors themselves

this firm, the reverse flow inventory management focuses on returnable packaging to be reinserted it productive process. These packaging are classified into two families: (A) Racks Tetra Pack and Tetra Pack; and (B) Boxes and laminates.

Considering the characteristics of the company, two managers are responsible for managing the return of packaging and its inventory management. They were named here as $\mathrm{DM}_{1}$ and $\mathrm{DM}_{2}$.

\section{Step 1 - Maps elaboration}

Firstly, two planning meetings were held in which the gap identified in the literature about inventory management in the reverse flow for returnable packaging was discussed. Then, it was possible debated the problem context. Here they were sensitized on the problem addressed, being aware of the importance of the study and the consequences that it would bring to the company. After that, the DMs were interviewed individually to identify their viewpoints and opinions and, then, the individual maps were constructed. The label defined by the $\mathrm{DM}_{1}$ for the problem was: "Which aspects are relevant in the inventory management process for returnable packaging?" Then, the DM $\mathrm{DM}_{1}$ issued the primary evaluation elements (PEE) that were: Cost,
Profit, Deployment, Training, Interpersonal relationship, Transportation, Information system (IS), and Work quality. In addition, the $\mathrm{DM}_{1}$ defined the concepts linked to PEE, that were: to have the justified cost, to generate profit, to preserve the environment, to be able to implant, to offer adequate training, to have a good interpersonal relationship, to have transport availability, to have an IS to support the management, and to provide quality work. Finally, the $\mathrm{DM}_{1}$ argued on each of the PEE in order to obtain other concepts until he feels satisfied with his map. The same steps were followed for $\mathrm{DM}_{2}$. Thus, the facilitator aggregated both maps into a global map, the strategic map. During a meeting, this strategic map was expanded by the DMs, and the map was concluded considering the acceptability of them until reach in the final map, as showed in Figure 2.

\section{Step 2 - Map analysis}

The constructs and their classifications are presented in Table 1.

In this case study, as can be seen in Table 1, eight constructs were classified as tails $\left(\mathrm{C}_{1}, \mathrm{C}_{2}, \mathrm{C}_{3}, \mathrm{C}_{4}, \mathrm{C}_{5}, \mathrm{C}_{6}, \mathrm{C}_{7}\right.$ and $\left.\mathrm{C}_{8}\right)$. Among them, the construct $\mathrm{C}_{6}$, e.g., explores the fact that the returned packaging must have an acceptable level of quality 


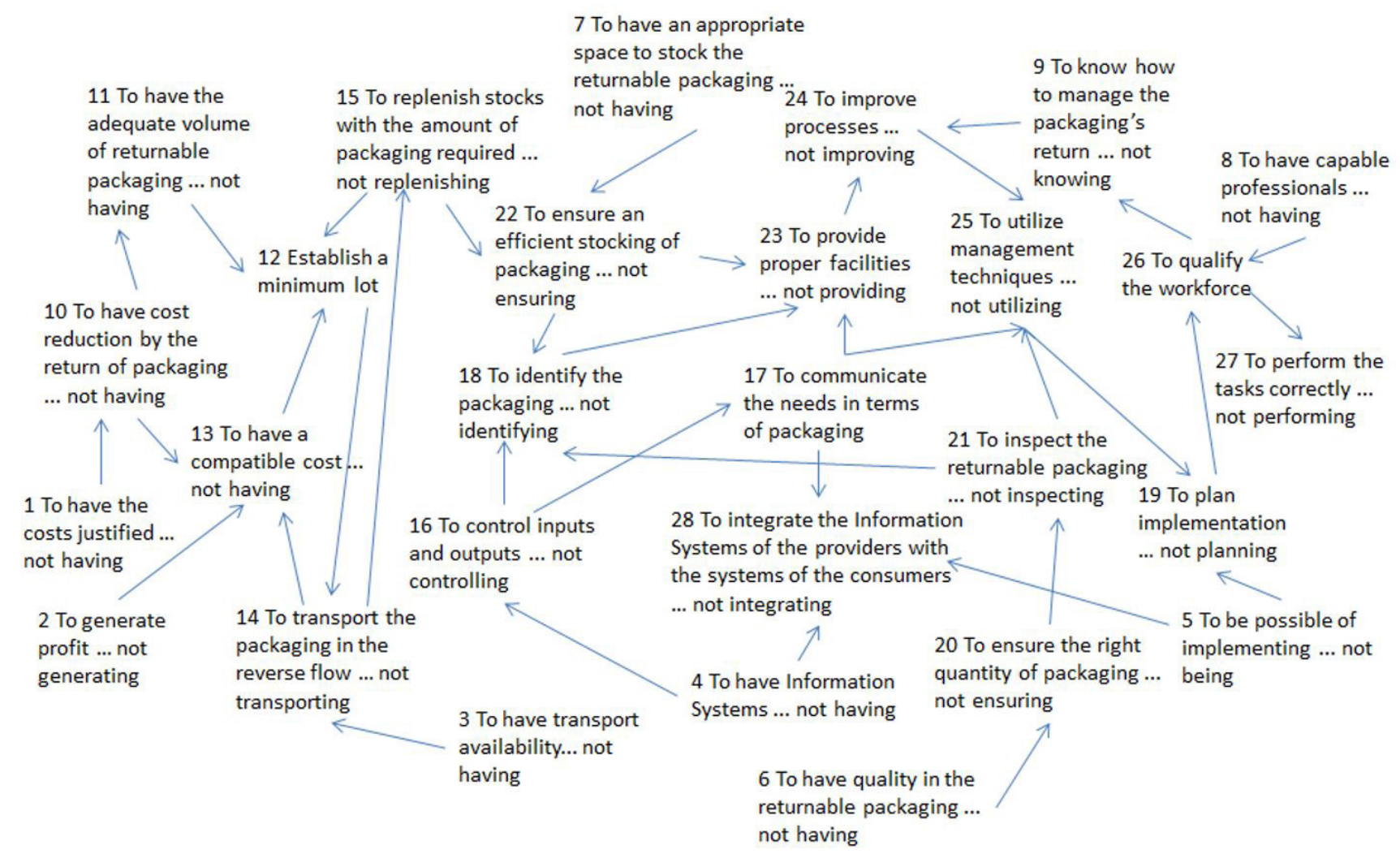

Figure 2. Strategic Map with Group Interaction Source: The authors themselves

Table 1.Maps constructs classification

\begin{tabular}{|c|c|c|c|c|c|}
\hline Code & Constructs & IG & EG & DG & Classification \\
\hline $\mathrm{C}_{1}$ & To have the costs justified ... not having & 0 & 1 & 1 & Tail \\
\hline $\mathrm{C}_{2}$ & To generate profit ... not generating & 0 & 1 & 1 & Tail \\
\hline $\mathrm{C}_{3}$ & To have transport availability... not having & 0 & 1 & 1 & Tail \\
\hline $\mathrm{C}_{4}$ & To have Information Systems ... not having & 0 & 2 & 2 & Tail / Strategic \\
\hline $\mathrm{C}_{5}$ & To be possible of implementing ... not being & 0 & 2 & 2 & Tail / Strategic \\
\hline $\mathrm{C}_{6}$ & To have quality in the returnable packaging ... not having & 0 & 1 & 1 & Tail \\
\hline $\mathrm{C}_{7}$ & To have an appropriate space to stock the returnable packaging ... not having & 0 & 1 & 1 & Tail \\
\hline $\mathrm{C}_{8}$ & To have capable professionals ... not having & 0 & 1 & 1 & Tail \\
\hline $\mathrm{C}_{9}$ & To know how to manage the packaging's return ... not knowing & 1 & 1 & 2 & \\
\hline $\mathrm{C}_{10}$ & To have cost reduction by the return of packaging ... not having & 1 & 2 & 3 & \\
\hline $\mathrm{C}_{11}$ & To have the adequate volume of returnable packaging ... not having & 1 & 1 & 2 & \\
\hline $\mathrm{C}_{12}$ & Establish a minimum lot & 3 & 1 & 4 & Dominant \\
\hline $\mathrm{C}_{13}$ & To have a compatible cost ... not having & 3 & 1 & 4 & Dominant \\
\hline $\mathrm{C}_{14}$ & To transport the packaging in the reverse flow ... not transporting & 2 & 2 & 4 & Dominant \\
\hline $\mathrm{C}_{15}$ & To replenish stocks with the amount of packaging required ... not replenishing & 1 & 2 & 3 & \\
\hline $\mathrm{C}_{16}$ & To control inputs and outputs ... not controlling & 1 & 2 & 3 & \\
\hline $\mathrm{C}_{17}$ & To communicate the needs in terms of packaging & 1 & 3 & 4 & $\begin{array}{c}\text { Explosion/ } \\
\text { Dominant/ } \\
\text { Strategic }\end{array}$ \\
\hline
\end{tabular}


Table 1.Continued...

\begin{tabular}{|c|c|c|c|c|c|}
\hline Code & Constructs & IG & EG & DG & Classification \\
\hline $\mathrm{C}_{18}$ & To identify the packaging ... not identifying & 3 & 1 & 4 & Dominant \\
\hline $\mathrm{C}_{19}$ & To plan implementation ... not planning & 2 & 1 & 3 & \\
\hline $\mathrm{C}_{20}$ & To ensure the right quantity of packaging ... not ensuring & 1 & 1 & 2 & \\
\hline $\mathrm{C}_{21}$ & To inspect the returnable packaging ... not inspecting & 1 & 3 & 4 & $\begin{array}{c}\text { Explosion/ } \\
\text { Dominant/ } \\
\text { Strategic }\end{array}$ \\
\hline $\mathrm{C}_{22}$ & To ensure an efficient stocking of packaging ... not ensuring & 2 & 2 & 4 & Dominant \\
\hline $\mathrm{C}_{23}$ & To provide proper facilities ... not providing & 3 & 1 & 4 & Dominant \\
\hline $\mathrm{C}_{24}$ & To improve processes ... not improving & 2 & 1 & 3 & \\
\hline $\mathrm{C}_{25}$ & To utilize management techniques ... not utilizing & 3 & 1 & 4 & Dominant \\
\hline $\mathrm{C}_{26}$ & To qualify the workforce & 2 & 2 & 4 & $\begin{array}{c}\text { Dominant/ } \\
\text { Strategic }\end{array}$ \\
\hline $\mathrm{C}_{27}$ & To perform the tasks correctly ... not performing & 1 & 0 & 1 & Head \\
\hline$C_{28}$ & $\begin{array}{l}\text { To integrate the Information Systems of the providers with the systems of the } \\
\text { consumers ... not integrating }\end{array}$ & 4 & 0 & 4 & $\begin{array}{l}\text { Head/Implosion/ } \\
\text { Dominant }\end{array}$ \\
\hline
\end{tabular}

Source: The authors themselves

that justifies their reinsertion in the productive channel. It makes quality a crucial point in the reverse flow inventory management process.

Two constructs were classified as heads $\left(\mathrm{C}_{27}\right.$ and $\mathrm{C}_{28}$ ). Among them, construct $\mathrm{C}_{27}$, e.g., is coherent with that classification because when tasks are performed correctly the losses in the process will decrease and the company gains with this.

Five constructs were classified as strategic options $\left(C_{4}, C_{5}, C_{17}, C_{21}\right.$ and $\left.C_{26}\right)$. Among them, construct $C_{26}$, e.g., is one of the options presented in order to reach the goal of construct $\mathrm{C}_{27}$, through the correct performance of the tasks.

Only one construct was classified as implosion $\left(C_{28}\right)$. This construct addresses the integration of the Information System and customers system. This integration is important in order to coordinate the activities needed for returned the packaging.

Two constructs were classified as explosions $\left(\mathrm{C}_{17}\right.$ and $\left.\mathrm{C}_{21}\right)$. Construct $C_{21}$, e.g., is important since the inspection is necessary in order to verify and guarantee the quality of the packaging that will be reinserted in the manufacturing. Thus, inspection is a crucial point to the whole process.

Eleven constructs were classified as dominants $\left(\mathrm{C}_{12}, \mathrm{C}_{13}, \mathrm{C}_{14}, \mathrm{C}_{17}, \mathrm{C}_{18}, \mathrm{C}_{21}, \mathrm{C}_{22}, \mathrm{C}_{23}, \mathrm{C}_{25}, \mathrm{C}_{26}\right.$ and $\left.\mathrm{C}_{28}\right)$. Among them, construct $\mathrm{C}_{12}$, e.g., addresses the establishment of a minimum lot. This establishment has a high impact in the packaging transport, since the transport cost will be justified by the quantity established.
Six constructs have received more than one classification

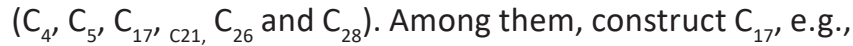
was classified as strategic option, explosion and dominant. As strategic option, this construct explains that a faster performance of the activities may be verified when there is a timely communication about returned packaging. Already as explosion, when the need activities are not performed correctly, the construct $\mathrm{C}_{17}$ will mean the major cause of inefficiency in the process. For that reason, this construct was classified as dominant, too; and this fact demonstrates its relevance to the whole process.

Finally, eight constructs didn't receive any classification $\left(C_{9}, C_{10}, C_{11}, C_{15}, C_{16}, C_{19}, C_{20}\right.$ and $\left.C_{24}\right)$. Despite this, these construct are important in the map. The construct $\mathrm{C}_{11}$, e.g., was necessary as a transition construct in order to achieve the construct $\mathrm{C}_{12}$.

Therefore, as mentioned before, the dominants constructs were used to identify the CSF. Some of these constructs were aggregated because they have a convergence in their meaning resulting in only one CSF.

Thus, nine CSFs were surveyed and they were shown in Table 2. The DMs confirmed that these CSFs surveyed are proper the reverse flow inventory management process for returnable packaging in their company.

\section{Step 3 - Critical Success Factors analysis}

The returnable packaging Volume must be compatible with the demand of the organization in question. So that, a minimum lot can be establish as a basis to enable their reintegration into the productive channel. 
Table 2. CSF surveyed

\begin{tabular}{|c|l|c|}
\hline Code & \multicolumn{1}{|c|}{ Dominant Constructs } & FCS surveyed \\
\hline$C_{12}$ & Establish a minimum lot & Volume \\
\hline$C_{13}$ & To have a compatible cost ... not having & Cost \\
\hline$C_{14}$ & To transport the packaging in the reverse flow ... not transporting & Speed \\
\hline$C_{17} / C_{28}$ & $\begin{array}{l}\text { To communicate the needs in terms of packaging and to integrate the Information Systems } \\
\text { of the providers with the systems of the consumers ... not integrating }\end{array}$ & Information Systems \\
\hline$C_{18}$ & To identify the packaging ... not identifying & Identifications Systems \\
\hline$C_{21}$ & To inspect the returnable packaging ... not inspecting & Quality \\
\hline$C_{22} / C_{25}$ & $\begin{array}{l}\text { To ensure an efficient stocking of packaging ... not ensuring and to utilize management } \\
\text { techniques ... not utilizing }\end{array}$ & $\begin{array}{c}\text { Inventory Management } \\
\text { Techniques }\end{array}$ \\
\hline$C_{23}$ & To provide proper facilities ... not providing & Facilities \\
\hline$C_{26}$ & To qualify the workforce & Human Resources \\
\hline
\end{tabular}

Source: The authors themselves

The main inventory management Costs in the reverse flow were:

$\checkmark$ Reuse Cost: the returnable packaging is justified when its reuse cost is less than the acquire cost of new one;

$\checkmark$ Development Cost: the development cost of a inventory management system in the reverse flow must to be less than in the direct flow; and

$\checkmark$ Inventory Cost: it will be reduced as material reuse takes place.

The Speed aspect has been identified to give significance to the frequency of return of the packaging, since there is uncertainty in the predictability of their return. Such frequency must to take in consideration the manufacturing activities in order to guarantee its resupply.

The Information System has the function of supporting inventory management activities in the reverse flow by controlling inputs, outputs and the processes needs;

The Identification Systems arise from the need of better controls of inputs and outputs, in order to speed up the insertion of these data into the IS. Such identification systems can be: labels, bar code, QR-code, etc.

The returned packaging must meet some Quality requirements. For that, inspections activities are conducted such as:

$\checkmark$ Low value added returnable packaging: this does not need sophisticated inspection methods, requiring low investments for it. The inspections activities can be conduct in the source or company, or both, since they are able to conducted it with low cost; and $\checkmark$ High value added returnable packaging: due to the high investment in inspection methods, it recommended inspection activities are done only in source or company, depending on the interest for each one.

The Inventory Management Techniques in the reverse flow should be chosen considering the system features as a whole, i.e., direct and reverse flow.

In reverse flow, the inventory Facilities should be designed in order to does not detract the quality. According to their classification, if the returned packaging does not pose a risk to others material quality, it can be storage in the same space; otherwise, it must be storage in a proper space.

Finally, the Human Resources play a fundamental role in the inventory management in the reverse flow. Thus, they should be: motivated, integrated, skilled and trained.

\section{DISCUSSIONS}

Regarding the behaviour of the DMs during the proposed methodology application some points were observed.

First, before the beginning of the application, the DMs seemed to feel uncomfortable. Moreover, managers did not have the appropriate knowledge to improve inventory management process in reverse flow. They also did not know how to identify the CSF in their reality. So, two planning meetings were needed to get around this situation.

Second, the DMs attested that their viewpoints were well represented in the strategic map. They seemed satisfied with the results. Cunha and Morais (2016) argued that the satisfaction of DMs may indicate an appropriate measure of success in the process. In this sense, they recommended that in addition to the final result it is important to verify 
the satisfaction of those involved about the procedure itself, i.e., about the dynamics performed and the information made available. In the end, those involved must agree to the decision even when it was not their initial preference.

However, it was possible due to the process was conducted into two phases. In other words, first the individual maps were generated, and, after that, they were aggregated into one. If a workshop had been conducted since the beginning, probably this result would not possible due to the influence from decision maker stronger personality. According to Bouyssou et al. (2006), the major relevance of cognitive mapping is its ability to promote interaction among stakeholders. In this context, the facilitator is characterized by an important agent in the conduct of discussions and draws CMs according to the DMs feedbacks and discussions during the meeting.

Moreover, Gardas et al. (2019) have had as main objective the identification of CSF for the reusable packaging management in order to establish a sustainable system. For that, they made a literature review and they presupposed a structured situation that may not deal with contingencies specific characteristics from each context. However, in the opposite direction, our study proposed a Strategic Map analyse which was able to survey the CSF objectively in messy and complex situations. This approach minimized conflicts and facilitated the discussions on these factors. The adoption of the CSF concept was fundamental to assist decision makers on identifying the areas that managers must pay more attention and to develop effective strategies to improve these areas in order to benefit the whole chain for the inventory management implementation of returnable packaging in reverse flow.

Finally, Gupta et al. (2019) affirmed that CSF study allows managers to understand the necessities of the processes in order to guide them to provide a sustainable quality of service so as to meet market demands. In the case studied, the DMs reported that they will deploy these CSF into quantifiable measures and they will define acceptable pattern levels to the operations. These measures will be use as a feedback about the operations performance. From that, the DMs will know the operations that need improvements.

\section{CONCLUDING REMARKS}

This study concluded that the proposed methodology achieved the objective, since it was consistent and it was able to survey of a set of CSFs to the problem situation, i.e., in the reverse flow inventory management process for returnable packaging.
The main contribution was study a GAP in the literature about CSF in the reverse flow inventory management process for returnable packaging, through: (a) a methodology adequate in messy, complex and unstructured situations, rather than structured situations; (b) a problem structuring method (PSM), the SODA, applied to survey CSFs, this methodology has not yet been used in this context, especially in reverse logistics; (c) the proposed methodology allowed a cyclic analysis and comprehension of the multiple perspectives, important in group decision maker environments.

The CSFs impact directly on profits, processes performance and in the competitive environment. Thus, survey these in reverse logistics proved to be relevant for a better performance on inventory management, a decreasing quantity of new packaging being utilized, reducing operating costs, allowing more capital to be invested in new projects in the company.

This study was important too in order to help managers to understand which CSF may affect the post-consumption channel, because these packaging cannot be disposed inadequately in the environment. Thus, packaging needs to return to be evaluated and receive the correct reinsertion process or disposal.

The surveyed CSFs are specific to the presented case study. However, other organizations in same or other business sectors can replicate this study using the same methodology to identify their own CSFs.

As a future work, a study in other companies from the same business would be interesting to verify if there are convergences on the CSFs in order to identify the best practices in the RL inventory management process for returnable packaging and help the firms to achieve competitiveness.

\section{ACKNOWLEDGMENTS}

This work had partial support from Fundação de Amparo à Ciência e Tecnologia do Estado de Pernambuco (FACEPE) and Coordenação de Aperfeiçoamento de Pessoal de Nível Superior (CAPES).

\section{REFERENCES}

Agrawal, S., Singh, R.K. and Murtaza, Q. (2016), “Prioritizing critical success factors for reverse logistics implementation using fuzzy-TOPSIS methodology", Journal of Industrial Engineering International, Vol. 12, No. 1, pp. 15-27. http:// dx.doi.org/10.1007/s40092-015-0124-8. 
Alhuraish, I., Robledo, C. and Kobi, A. (2017), "A comparative exploration of lean manufacturing and six sigma in terms of their critical success factors", Journal of Cleaner Production, Vol. 164, pp. 325-337. http://dx.doi. org/10.1016/j.jclepro.2017.06.146.

Ali, U. and Kidd, C. (2013), "Critical success factors for configuration management implementation", Industrial Management \& Data Systems, Vol. 113, No. 2, pp. 250-64. http://dx.doi.org/10.1108/02635571311303569.

Alreemy, Z., Chang, V., Walters, R. et al. (2016), "Critical success factors (CSFs) for information technology governance (ITG)", International Journal of Information Management, Vol. 36, No. 6, pp. 907-16. http://dx.doi.org/10.1016/j. ijinfomgt.2016.05.017.

Arlinghaus, S., Arlinghaus, W.C. and Harary, F. (2002), Graph theory and geography: an interactive view, New York, John Wiley and Sons.

Atamer, B., Bakal, I. and Bayindir, Z. (2013), “Optimal pricing and production decisions in utilizing reusable containers", International Journal of Production Economics, Vol. 143, No. 2, pp. 222-32. http://dx.doi.org/10.1016/j.ijpe.2011.08.007.

Bai, C. and Sarkis, J. (2013), "A grey-based DEMATEL model for evaluating business process management critical success factors", International Journal of Production Economics, Vol. 146, No. 1, pp. 281-92. http://dx.doi.org/10.1016/j. ijpe.2013.07.011.

Banihashemi, S., Hosseini, M., Golizadeh, H. et al. (2017), "Critical success factors (CSFs) for integration of sustainability into construction project management practices in developing countries", International Journal of Project Management, Vol. 35, No. 6, pp. 1103-19. http://dx.doi.org/10.1016/j. ijproman.2017.01.014.

Beitzen-Heineke, E.F., Balta-Ozkan, N. and Reefke, H. (2017), "The prospects of zero-packaging grocery stores to improve the social and environmental impacts of the food supply chain", Journal of Cleaner Production, Vol. 140, pp. 1528-41. http://dx.doi.org/10.1016/j.jclepro.2016.09.227.

Bhuasiri, W., Xaymoungkhoun, O., Zo, H. et al. (2012), "Critical success factors for e-learning in developing countries: A comparative analysis between ICT experts and faculty", Computers \& Education, Vol. 58, pp. 843-55.

Bogataj, M. and Grubbstr, R.W. (2013), "Transportation delays in reverse logistics", International Journal Production Economics, Vol. 143, pp.395-402. http://dx.doi.org/10.1016/j. ijpe.2011.12.007.

Bottani, E., Montanari, R., Rinaldi, R. et al. (2015), “Modeling and multi-objective optimization of closed loop supply chains:
A case study", Computers \& Industrial Engineering, Vol. 87, No. 9, pp. 328-42. http://dx.doi.org/10.1016/j.cie.2015.05.009.

Bouyssou, D., Marchant, T., Pirlot, M. et al. (2006), Evaluation and decision models with multiple criteria-stepping stones for the analyst, Springer, Berlin.

Bouzon, M., Govindana, K., Rodriguez, C. et al. (2016), "Identification and analysis of reverse logistics barriers using fuzzy Delphi method and AHP", Resources, Conservation and Recycling, Vol. 108, pp. 182-97. http://dx.doi.org/10.1016/j. resconrec.2015.05.021.

Brun, A. (2011), "Critical success factors of Six Sigma implementations in Italian companies", International Journal of Production Economics, Vol. 131, No. 1, pp. 158-64. http:// dx.doi.org/10.1016/j.ijpe.2010.05.008.

Carrano, A., Pazour, J., Roy, D. et al. (2015), "Selection of pallet management strategies based on carbon emissions impact", International Journal of Production Economics, Vol. 164, No. 6, pp. 258-70. http://dx.doi.org/10.1016/j. ijpe.2014.09.037.

Chenhall, R.H. (2003), "Management control systems design within its organizational context: findings from contingency-based research and directions for the future", Accounting, Organizations and Society, Vol. 28, No. 3, pp. 127-68. http://dx.doi.org/10.1016/S0361-3682(01)00027-7.

Cherubini, S., Lasevoli, G. and Michelini, L. (2015), “Productservice systems in the electric car industry: critical success factors in marketing", Journal of Cleaner Production, Vol. 97, pp. 40-9. http://dx.doi.org/10.1016/j.jclepro.2014.02.042.

Chew, E. and Huang, H. (2002), "Performance measures for returnable inventory: a case study", Production Planning and Control, Vol. 13, No. 5, pp. 462-9. http://dx.doi. org/10.1080/09537280210142790.

Chileshe, N., Rameezdeen, R., Hosseini, M.R. et al. (2015), "Barriers to implementing reverse logistics in South Australian construction organisations", Supply Chain Management, Vol. 20, No. 2, pp. 179-204. http://dx.doi.org/10.1108/SCM-102014-0325.

Costantino, F., Di Gravio, G. and Nonino, F. (2015), “Project selection in project portfolio management: An artificial neural network model based on critical success factors", International Journal of Project Management, Vol. 33, No. 8, pp. 1744-54. http://dx.doi.org/10.1016/j.ijproman.2015.07.003.

Cunha, A.A.R. and Morais, D.C. (2016), "Analysing the use of cognitive maps in an experiment on a group decision process", The Journal of the Operational Research Society, Vol. 67, No. 12, pp. 1459-68. 
Cunha, A.A.R. and Morais, D.C. (2017), "Problem structuring methods in group decision making: a comparative study of their application", Operational Research an International Journal, Vol. 18, pp. 1-20.

Cunha, A.A.R., Silva Filho, J.L. and Morais, D.C. (2016), "Aggregation cognitive maps procedure for group decision analysis", Kybernetes, Vol. 45, No. 4, pp. 589-603. http:// dx.doi.org/10.1108/K-04-2015-0092.

Da, Q., Huang, Z. and Zhang, Q. (2004), "Current and future studies on structure of the reverse logistics system: a review", Chinese Journal of Management Science, Vol. 12, pp. 131-38.

Dang, S. and Chu, L. (2016), "Evaluation framework and verification for sustainable container management as reusable packaging", Journal of Business Research, Vol. 69, No. 5, pp. 1949-55. http://dx.doi.org/10.1016/j.jbusres.2015.10.086.

Dem, H. and Prasher, L. (2013), "Imperfect production system under reverse logistics in stock-out situation: EPQ model", Advances in Decision Sciences, Vol. 2013, pp. 1-10.

Doorsselaer, K. and Lox, F. (1999), "Estimation of the energy needs in life cycle analysis of one-way and returnable glass packaging", Packaging Technology and Science. An International Journal, Vol. 12, No. 5, pp. 235-39.

Dubiel, M. (1996), "Costing Structures of Reusable Packaging Systems. International Journal Packaging Technology and Science, Vol. 9, No. 5, pp. 237-54.

Eden, C. and Ackermann, F. (2001), "SODA - The Principles", in Rosenhead, J. and Mingers, J. (Eds.), Rational Analysis for a Problematic World Revisited", John Wiley \& Sons, Chichester.

Eden, C. and Ackermann, F. (2006), "Where next for problem structuring methods", Journal of the Operational Research Society, Vol. 57, pp. 766-768.

Eden, C. (2004), "Analyzing cognitive maps to help structure issues or problems", European Journal of Operational Research, Vol. 159, pp. 673-686.

Farel, R., Yannou, B., Ghaffari, A. et al. (2013), "A cost and benefit analysis of future end-of-life vehicle glazing recycling in France: a systematic approach", Resources, Conservation and Recycling, Vol. 74, pp. 54-65.

Fayaz, A., Kamal, Y., Amin, S. et al. (2017), "Critical success factors in information technology projects", Management Science Letters, Vol. 7, No. 2, pp. 73-80. http://dx.doi. org/10.5267/j.msl.2016.11.012.

Fontana, M.E. and Holanda, C.L.S. (2019), "A multicriteria decision analysis on strategic operations in post-sale reverse logistics: a case study", Produção em Foco, Vol. 9, No. 1, pp. 73-97.

Gardas, B., Raut, R. and Narkhede, B. (2019), "Identifying critical success factors to facilitate reusable plastic packaging towards sustainable supply chain management", Journal of Environmental Management, Vol. 236, pp. 81-92.

Georgiou, I. (2010), "Cognitive Mapping and Strategic Options Development and Analysis (SODA)", in Cochran, J.J., Cox Junior, L.A., Keskinocak, P. et al. (Eds.), Wiley Encyclopedia of Operations Research and Management Science. John Wiley \& Sons, Hoboken. http://dx.doi.org/10.1002/9780470400531. eorms0974.

Georgiou, I. (2012), "Messing about in transformations: Structured systemic planning for systemic solutions to systemic problems", European Journal of Operational Research, Vol. 223, No. 2, pp. 392-406. http://dx.doi. org/10.1016/j.ejor.2012.06.010.

Govindan, K. and Soleimani, H. (2017), "A review of reverse logistics and closed-loop supply chains: a Journal of Cleaner Production focus", Journal of Cleaner Production, Vol. 142, pp. 371-384.

Grimes-Casey, H.G., Seager, T.P., Theis, T.L. et al. (2007), "A game theory framework for cooperative management of refillable and disposable bottle lifecycles", Journal of Cleaner Production, Vol. 15, No. 17, pp. 1618-27. http://dx.doi. org/10.1016/j.jclepro.2006.08.007.

Guarnieri, P.E., Silva, L.C., Levino, N.A. (2016), "Analysis of electronic waste reverse logistics decisions using Strategic Options Development Analysis methodology: A Brazilian case", Journal of Cleaner Production, Vol. 133, pp. 1105-17. http://dx.doi.org/10.1016/j.jclepro.2016.06.025

Guide, D. and Van Wassenhove, L. (2009), "The evolution of closed-loop supply chain research", Operations Research, Vol. 57, pp. 10-18. http://dx.doi.org/10.1287/opre.1080.0628

Gupta, A., Singh, R. and Suri, P. (2019), “Prioritizing critical success factors for sustainable service quality management by logistics service providers vision", The Journal of Business Perspective, Vol. 22, No. 3, pp. 295-305.

Himme, A. (2012), "Critical success factors of strategic cost reduction results from an empirical survey of German cost reduction projects", Journal of Management Control, Vol. 23, No. 3, pp. 183-210. http://dx.doi.org/10.1007/s00187012-0157-8.

Ika, L., Diallo, A. and Thuillierb, D. (2012), “Critical success factors for World Bank projects: An empirical investigation", International Journal of Project Management, 
Vol. 30, No. 1, pp. 105-11. http://dx.doi.org/10.1016/j. ijproman.2011.03.005.

Keisler, J., Turcotte, D., Drew, R. et al. (2014), “Value-focused thinking for community-based organizations: objectives and acceptance in local development", EURO Journal on Decision Processes, Vol. 2, pp. 221-56.

Kim, T., Glock, C. and Kwon, Y. (2014), “A closed-loop supply chain for deteriorating products under stochastic container return times", Omega, Vol. 43, No. 3, pp. 30-40. doi:10.1016/j. omega.2013.06.002.

Konsti-Laakso, S. and Rantala, T. (2018), "Managing community engagement: A process model for urban planning", European Journal of Operational Research, Vol. 268, pp. 1040-49.

Lee, C.K.M. and Lam, J.S.L. (2012), "Managing reverse logistics to enhance sustainability of industrial marketing", Industrial Marketing Management, Vol. 41, No. 4, pp. 589-98. http://dx.doi.org/10.1016/j.indmarman.2012.04.006.

Levi, M., Cortesi, S., Vezzoli, C. et al. (2011), "A Comparative Life Cycle Assessment of Disposable and Reusable Packaging for the Distribution of Italian Fruit and Vegetables", Packaging Technology \& Science, Vol. 24, No. 7, pp. 387-400. http:// dx.doi.org/10.1002/pts.946.

Mangla, S.K., Govindan, K. and Luthra, S. (2015), "Critical success factors for reverse logistics in Indian industries: A structural model", Journal of Cleaner Production, Vol. 129, pp. 608-621. http://dx.doi.org/10.1016/j.jclepro.2016.03.124.

Matar, N., Jaber, M. and Searcy, C. (2014), "A reverse logistics inventory model for plastic bottles", International Journal of Logistics Management, Vol. 25, No. 2, pp. 315-33.

Mazeika Bilbao, A., Carrano, A., Hewitt, M. et al. (2011), “On the environmental impacts of pallet management operations", Management Research Review, Vol. 34, No. 11, pp. 1222-36. http://dx.doi.org/10.1108/01409171111178765.

Menesatti, P., Canali, E., Sperandio, G. et al. (2012), “Cost and waste comparison of reusable and disposable shipping containers for cut flowers", Packaging Technology \& Science, Vol. 25, No. 4, pp. 203-15. http://dx.doi.org/10.1002/pts.974.

Midgley, G., Cavana, R., Brocklesby, J. et al. (2013), "Towards a new framework for evaluating systemic problem structuring methods", European Journal of Operational Research, Vol. 229, pp. 143-54.

Mingers, J. and Rosenhead, J. (2004), “Problem structuring methods in action", European Journal of Operational Research, Vol. 152, pp. 530-54.
Mollenkopf, D., Closs, D., Twede, D. et al. (2005), “Assessing the viability of reusable packaging: a relative cost approach", Journal of Business Logistics, Vol. 26, pp. 169-197. http:// dx.doi.org/10.1002/j.2158-1592.2005.tb00198.x.

Morais, D. and De Almeida, A. (2009), "Integrated model of problem structuring and multicriteria group decision making for social sustainable development", Brazilian Journal of Operations \& Production Management, Vol. 6, No. 2, pp. 27-49.

Muniz Junior, J., Cunha, J., Almeida, R. et al. (2017), "The knowledge management in business strategies and reverse logistics", Brazilian Journal of Operation \& Production Management, Vol. 14, pp. 28-36. http://dx.doi.org/10.14488/ BJOPM.2017.v14.n1.a4

Ozorhon, B. and Karahan, U. (2017), "Critical success factors of building information modeling implementation", Journal of Management in Engineering, Vol. 33, No. 3, http://dx.doi. org/10.1061/(ASCE)ME.1943-5479.0000505.

Palsson, H., Finnsgard, C. and Wänström, C. (2013), "Selection of packaging systems in supply chains from a sustainability perspective: The case of Volvo", Packaging Technology \& Science, Vol. 26, No. 5, pp. 289-310. http:// dx.doi.org/10.1002/pts.1979.

Raj, R., Kaliraman, N., Chandra, S. et al. (2014), "A production inventory model with experimental demand rate and reverse logistics", International Journal of Industrial Engineering Computations, Vol. 5, No. 4, pp. 521-42.

Rodríguez-Segura, E., Ortiz-Marcosa, I., Romero, J. et al. (2016), "Critical success factors in large projects in the aerospace and defense sectors", Journal of Business Research, Vol. 69, No. 11, pp. 5419-25. http://dx.doi.org/10.1016/j. jbusres.2016.04.148.

Rogers, D.S., Tibben-Lembke, R. (1999). Going backwards: Reverse logistics trends and practices. Reverse Logistics Executive Council (RLEC), Pittsburgh, PA.

Rosenhead, J. and Mingers, J. (2001), Rational Analysis for a Problematic World: Problem Structuring Methods for Complexity, Uncertainty and Conflict, 2nd ed., John Willey \& Sons, West Sussex.

Rouwette, E., Bastings, I. and Blokker, H. (2011), "A comparison of group model building and strategic options development and analysis", Group Decision and Negotiation, Vol. 20, No. 6, pp. 781-803. http://dx.doi.org/10.1007/ s10726-010-9207-5.

Sampedro, E., Sánchez, M., López, J. et al. (2010), “The environment as a critical success factor in the wine industry: implications for management control systems", Journal of 
Wine Research, Vol. 21, No. 2-3, pp. 179-95. http://dx.doi. org/10.1080/09571264.2010.530102.

Silva, D.A.L., Renó, G., Sevegnani, G. et al. (2013), Comparison of disposable and returnable packaging: A case study of reverse logistics in Brazil. Journal of Cleaner Production, Vol. 47, pp. 377-387. http://dx.doi.org/10.1016/j. jclepro.2012.07.057.

Singh, S., Walker, R. and Close, D. (1999), "Comparison of returnable paper and plastic corrugated packaging trays for the United States postal service", Journal of Testing and Evaluation, Vol. 27, No. 4, pp. 296-300. http://dx.doi. org/10.1520/JTE12227J.

Thoroe, L., Melski, A. and Schumann, M. (2009), "The impact of RFID on management of returnable containers", Electronic Markets, Vol. 19, No. 2-3, pp. 115-24. http://dx.doi. org/10.1007/s12525-009-0013-3.

Tsiliyannis, C. (2005), "Parametric analysis of environmental performance of reused/recycled packaging", Environmental Science \& Technology, Vol. 39, No. 24, pp. 9770-7. http:// dx.doi.org/10.1021/es050970s.

Turner, A. (2009), "Bottom-up community development: reality or rhetoric? The example of the Kingsmead Kabin in East London", Community Development Journal: An International Forum, Vol. 44, No. 2, pp. 230-47. http://dx.doi. org/10.1093/cdj/bsm047.

Twede, D. and Clarke, R. (2005), "Supply chain issues in reusable packaging", Journal of Marketing Channels, Vol. 12, pp. 7-26. http://dx.doi.org/10.1300/J049v12n01_02.

Usman, A. and Callum, K. (2013), "Critical success factors for configuration management implementation", Industrial Management \& Data Systems, Vol. 113, No. 2, pp. 250-64. http://dx.doi.org/10.1108/02635571311303569.
Veiga, M. (2013), "Analysis of efficiency of waste reverse logistics for recycling", Waste Management \& Research, Vol. 31 , No. 10 , pp. 26-34.

Videira, N., Herrera, H. and Mccardle-Keurentjes, M. (2016), "Evaluating facilitated modelling processes and outcomes: an experiment comparing a single and a multimethod approach in group model building", Group Decision and Negotiation, Vol. 25, No. 6, pp. 1277-318. http://dx.doi.org/10.1007/ s10726-016-9480-z.

Wang, W., Wenbin, L. and Mingers, J. (2015), "A systemic method for organizational stakeholder identification and analysis using Soft Systems Methodoly (SSM)", European Journal of Operational Research, Vol. 246, pp. 26-34.

Yolles, M. (2010), "Exploring complex sociocultural situations through soft operational research", Pesquisa Operacional, Vol. 30, No. 2, pp. 345-70. http://dx.doi. org/10.1590/S0101-74382010000200006.

Yui, K., Reis, C., Moro, M.F. et al. (2017), “Parameters involved in the internal reverse logistics of a hospital pharmacy", Brazilian Journal of Operations \& Production Management, Vol. 14, No. 3, pp. 318-26. http://dx.doi. org/10.14488/BJOPM.2017.v14.n3.a5.

Yusuf, Y., Olaberinjo, A., Papadopoulos, T., et al. (2017), "Returnable transport packaging in developing countries: drivers, barriers and business performance", Production Planning \& Control, Vol. 7287, pp. 1-30. http://dx.doi.org/1 0.1080/09537287.2017.1294271.

Zhang, Q, Segerstedt, A., Tsao, Y., et al. (2015), “Returnable packaging management in automotive parts logistics: Dedicated mode and shared mode". International Journal of Production Economics, Vol. 168, pp. 234-244. http://dx.doi. org/10.1016/j.ijpe.2015.07.002.

Received: 11 Feb 2019

Approved: 09 Apr 2019

How to cite: Sobrenome, A.B., Sobrenome, A.B. and Sobrenome, A.B. et al. (ANO), "Título do artigo", Brazilian Journal of Operations \& Production Management, Vol. 17, No. 1, e2020761. https://doi.org/10.14488/BJOPM.2020.003 